Printed in Great Britain

\title{
Studies of a Receptor for Felix 0-1 Phage in Salmonella minnesota
}

\author{
By A. A. LINDBERG \\ The Bacteriological Department, National Bacteriological Laboratory, \\ Stockholm, Sweden
}

(Accepted for publication 8 March 1967)

\begin{abstract}
SUMMARY
Isolated lipopolysaccharide from a rough mutant of Salmonella minnesota was shown to act as a receptor for Felix o-I bacteriophage. The isolated receptor structure could be dissociated by sodium deoxycholate with subsequent loss of receptor activity. When the deoxycholate was removed by dialysis the receptor activity was restored. Ultrasonic treatment destroyed the receptor activity and electron micrographs indicated that the ultrasonic treatment had altered the structure of the lipopolysaccharide. The experiments suggest that the inactivation of phages can be used as a test of the biological activity of a lipopolysaccharide. The interaction between the 0-I phage and the receptor structure was also studied with the aid of electron microscopy.
\end{abstract}

\section{INTRODUCTION}

The somatic polysaccharide antigens in the cell wall of enterobacteria were shown to act as receptors for bacteriophages by Levine \& Frisch (1933 a, b, 1934) and Burnet (1934). Weidel (I95I) and Hotchin, Dawson \& Elford (1952) observed the direct attachment of phages to isolated cell walls by examination in the electron microscope. Since then, the binding of phages to isolated cell walls as well as to purified receptor structures has been observed for a variety of Gram-positive and Gram-negative bacteria.

Felix 0-I phage (Felix \& Callow, 1943) lyses $96-99 \cdot 5 \%$ of Salmonella strains studied (Cherry, Davis, Edwards \& Hogan, 1954; Thal \& Kallings, 1955; Seidel, 1956). Some details of the particular relationship between the $0-1$ phage and salmonellas have been investigated (Kallings, 1967; Kallings \& Lindberg, 1967). The o-I phage adsorbs to and lyses the rough mutant Salmonella minnesota $\mathrm{R} 60$, while it does not adsorb to or lyse another rough mutant $S$. minnesota $\mathrm{R} 345$. According to chemical analysis (Lüderitz et al. 1965) the difference between these two rough organisms is that the polysaccharide of strain $\mathbf{R} 60$ contains 2-keto-3-deoxyoctonate (KDO), heptose, galactose, glucose and glucosamine, whereas the polysaccharide of strain R345 contains only $\mathrm{KDO}$, heptose, galactose and glucose.

As shown by Oroszlan \& Mora (1963) and Ribi et al. (1966) surface-active agents such as sodium laurylsulphate and sodium deoxycholate have the ability to dissociate endotoxins. The polysaccharide and lipopolysaccharide complexes are dissociated into subunits with concomitant loss of biological activity. When the agent is removed the subunits reaggregate to macromolecular complexes and the biological activity reappears. 
The present paper forms part of the studies on phage 0-I and Salmonella initiated by Dr L. O. Kallings, and describes the isolation from Salmonella minnesota of a lipopolysaccharide receptor structure for phage 0-I. The receptor activity of the isolated material was measured by its inactivation of the o-r phage. The depolymerization of the receptor structure by sodium deoxycholate was found to be correlated with a decrease in the o-I phage-inactivating capacity of the preparation. Upon removal of the surface-active agent the 0-I phage-inactivating ability was partly restored. The effect of ultrasonic treatment of the receptor structure was examined and the interaction between the 0-I phage and the receptor structure studied by electron microscopy.

\section{METHODS}

Bacteria. Salmonella minnesota strains R60 and R 345 were obtained from Dr L. O. Lüderitz (Max-Planck-Institut für Immunbiologie, Freiburg, Germany).

Phage. Felix 0-I phage was propagated on Salmonella paratyphi strain B 76 by the agar layer method (Adams, 1959). The phage was purified and concentrated by alternate cycles in a Christ Omega preparative ultracentrifuge at $5000 \mathrm{~g}$ to sediment debris, and at $30,000 \mathrm{~g}$ to sediment phage. The phage pellet was suspended in 0.01 M-phosphate buffer ( $\mathrm{pH} 7 \cdot 2$ ). The purified stock had a titre of $2.6 \times 10^{10}$ plaque-forming units (p.f.u./ml.). The phage suspension was stored at $+4^{\circ}$.

Media. The defined glucose + salts medium M 9 Adams (1959) was used for continuous cultivation of salmonella strains. This medium without glucose was used in the 0-I phage inactivation experiments and as a diluent. Nutrient broth (Difco) was used for the growth of Salmonella paratyphi $\mathbf{\text { B } 7 6 .}$

Preparation of lipopolysaccharide. Acetone-killed and dried bacteria were extracted by a modification of the phenol + water method of Westphal, Lüderitz \& Bister (1952). The collected aqueous layers were washed five times with chilled ether to remove residual phenol. Nitrogen was passed through the solution to remove ether. The opalescent solution was freeze-dried. A $2 \%(w / v)$ suspension of the material in distilled water was centrifuged at $105,000 \mathrm{~g}$ for $4 \mathrm{hr}$ in a Christ Omega preparative ultracentrifuge. The sediment was washed twice with water and recentrifuged. The pellet was freeze-dried. This lipopolysaccharide preparation (LPS) was used in the experiments.

Inactivation of phage o- 1 by the lipopolysaccharide. The LPS was diluted in medium $\mathbf{M} 9$ in twofold dilution steps. The o-I phage was diluted in medium $\mathrm{M}_{9}$ to $2 \times 10^{3}$ p.f.u./ml., which was the concentration used for inactivation experiments. One $\mathrm{ml}$. of each LPS dilution $+1.0 \mathrm{ml}$. O-I phage suspension were mixed and incubated in a water bath at $37^{\circ}$ for $60 \mathrm{~min}$. Assay of unadsorbed o-I phage was performed by adding $\mathrm{I} \cdot 0 \mathrm{ml}$. of the LPS + phage mixture to $8.5 \mathrm{ml}$. melted $0.6(\mathrm{w} / \mathrm{v})$ agar and $0.5 \mathrm{ml}$. of a $4 \mathrm{hr}$ broth culture of the indicator strain (Salmonella paratyphi B 76). Two $\mathrm{ml}$. of this mixture was poured on agar plates. After overnight incubation at $37^{\circ}$, the plaque numbers were recorded. The experiments were done in duplicate. The inactivation of the o-I phage was determined by comparing with controls where the LPS was replaced by the defined $M 9$ medium. The activity of the lipopolysaccharide was expressed as the concentration of LPS (dry wt/volume) causing $50 \%$ inhibition of the $0-1$ phage under the experimental conditions (PhI 50; Beumer \& Dirkx, 1960).

Treatment of lipopolysaccharide with sodium deoxycholate (SDC). The LPS was 
dissolved as completely as possible in $0.1 \mathrm{M}$-tris $+\mathrm{HCl}$ buffer $(\mathrm{pH} 8 \cdot 0)$. SDC dissolved in $0.1 \mathrm{M}$-tris buffer was added to the LPS solution to a final concentration of $0.5 \%$. The mixture was kept at $4^{\circ}$ overnight. The LPS +SDC suspension was dialysed three times against $0 \cdot \mathrm{I}$ M-tris-buffer $(\mathrm{pH} 8 \cdot 0)$ followed by dialysis five times against medium $\mathrm{M} 9\left(\mathrm{pH} 7 \cdot 4\right.$ at $\left.4^{\circ}\right)$.

Ultrasonic treatment of lipopolysaccharide. The LPS was dissolved as completely as possible in distilled water to give a $0.8 \%(\mathrm{w} / \mathrm{v})$ suspension. The suspension was kept in an ice-water bath and was treated in a water-cooled M.S.E. (Measuring \& Scientific Equipment Ltd, London) $500 \mathrm{~W}$. ultrasonic disintegrator at $20 \mathrm{kc}$. $/ \mathrm{s}$. for $5 \mathrm{~min}$. During this procedure the temperature did not rise above $46^{\circ}$. A sample was removed and tested immediately for $0-I$ phage inactivating ability and examined in the electron microscope.

Electron microscopy. The negative-staining technique (Brenner \& Horne, 1959) with $2 \%(\mathrm{w} / \mathrm{v})$ sodium tungstic silicate (STS; $\mathrm{pH} \mathrm{7 \cdot 2)}$ as the staining medium was used. For increasing the spreading quality of the suspension $0.1 \%(\mathrm{w} / \mathrm{v})$ bovine serum albumin was added to the STS solution. A thin layer of carbon was evaporated on to the surface of 400-mesh Formvar-coated specimen grids, from which the Formvar was subsequently dissolved away with amyl acetate. The phage and lipopolysaccharide materials were mixed with STS and applied as a drop on to the specimen grid. The solution remained on the grids for 60-120 sec. before the excess liquid was withdrawn, leaving a thin film. The specimens were examined with a JEM-5 Y electron microscope at a magnification of $\times 40,000$.

\section{RESULTS}

Lipopolysaccharide preparations from Salmonella minnesota strains $\mathrm{R} 60$ and R 345 were tested for their inactivating capacity towards phage 0-I. The experiments were made in a salt solution (M 9 medium without glucose) which gave a maximum adsorption of the O-I phage. Fig. I shows that the concentration of LPS from strain R60 necessary to inactivate $50 \%$ of the phage ( $\mathrm{PhI} 50$ ) varied from 0.4 to $0.9 \mu \mathrm{g}$. LPS $/ \mathrm{ml}$. for different preparations. Repeated experiments with LPS from strain R 345 showed no inactivation of the $0-I$ phage, even in suspensions containing $\mathrm{I} \cdot 0 \mathrm{mg}$. LPS $/ \mathrm{ml}$. These experiments suggest that LPS from strain $\mathrm{R} 60$ acted as a receptor for the 0-I phage while LPS from strain R 345 did not.

The interaction between the phage and receptor was observed with the electron microscope. Plate I, figs. I, 2 show the O-I phage with a polyhedral head, $60 \mathrm{~m} \mu$ in diameter, a tail 90-100 $\mathrm{m} \mu$ length with a base plate $25 \mathrm{~m} \mu$ wide with 6 tail fibres, generally extended. Plate I, fig. 3 shows the o-I phage adsorbed on to LPS of strain $\mathrm{R} 60$. The LPS is seen as long filaments several microns in length and $60-90 \AA$ wide. The o-I phage head is empty, clearly showing its polyhedral shape, the tail sheaths have contracted to a length of about $50^{\prime} \mathrm{m} \mu$. The contracted sheaths display longitudinal striations in contrast to the cross striations seen in extended tail sheaths. No tail fibres are visible. Plate 2, fig. 4 shows the O-I phage and LPS from strain R345. The LPS from $R 345$ shows the same modal pattern as the LPS of $R 60$, with long filaments of a rather uniform width. None of the phages has been adsorbed on to the LPS; they are seen with uncontracted tail sheaths. 


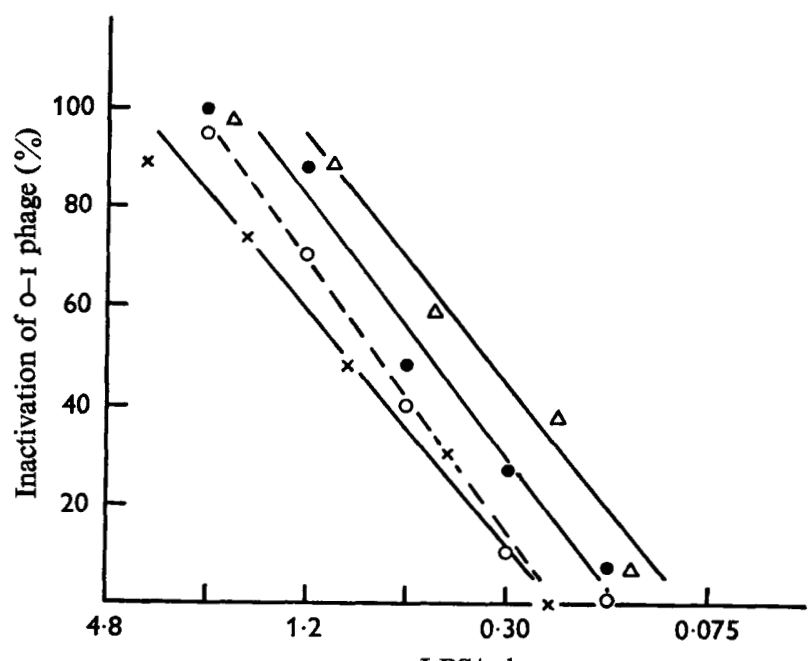

$\mu$ g. LPS $/ \mathrm{ml}$.

Fig. I. The o-I phage inactivating capacity of different samples of phenol + water-extracted lipopolysaccharides from Salmonella minnesota strain R60. The activity of the lipopolysaccharide (LPS) is expressed as the concentration of LPS (dry wt./vol.) necessary to inactivate $50 \%$ of the phage (PhI 50). $\times-\times, \mathrm{PhI} 50=0.91 \mu \mathrm{g} . \mathrm{LPS} / \mathrm{ml}$; $\mathrm{O}-\mathrm{O}, \mathrm{PhI} 50=$ $0.73 \mu \mathrm{g}$. LPS $/ \mathrm{ml}$. - - , PhI $50=0.5 \mathrm{I} \mu \mathrm{g}$. LPS $/ \mathrm{ml} . ; \triangle \triangle \triangle$, PhI $50=0.36 \mu \mathrm{g}$. LPS $/ \mathrm{ml}$.

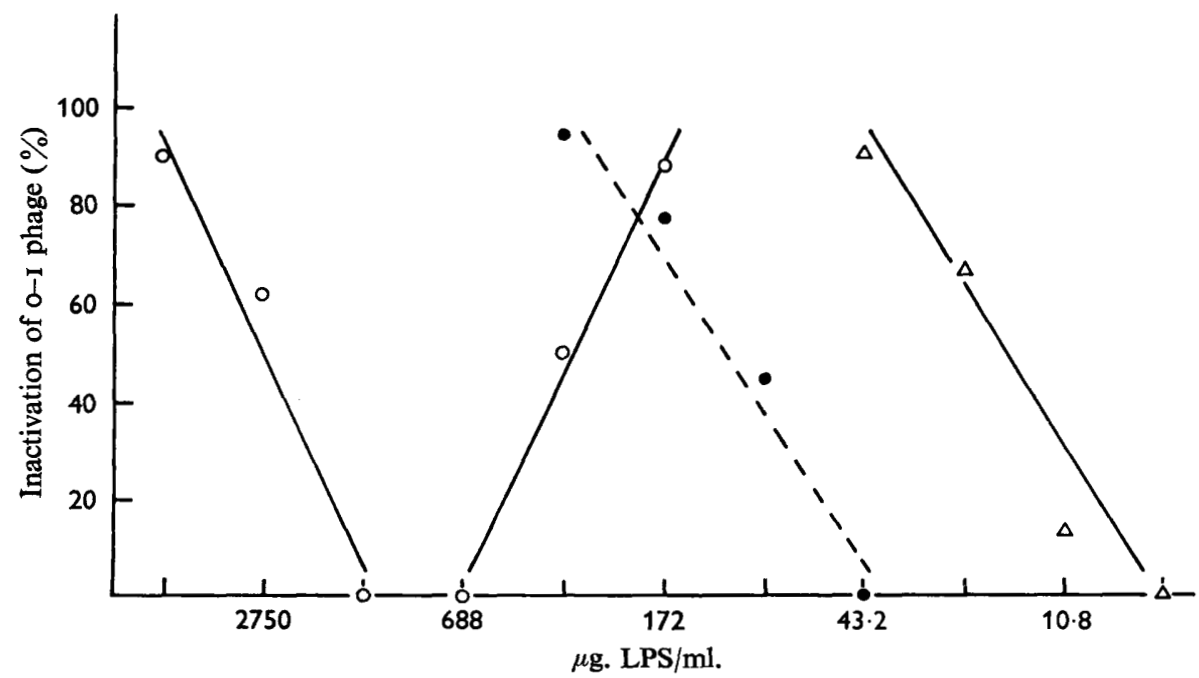

Fig. 2. Action of sodium deoxycholate on lipopolysaccharide (LPS) from Salmonella minnesota strain $\mathbf{R} 60$. The $0-1$ phage inactivating capacity of the LPS is expressed as $\mathrm{PhI} 50$. O-O, LPS of strain $\mathrm{R} 60$ treated with deoxycholate, PhI $50=2750 \mu \mathrm{g}$. LPS $/ \mathrm{ml}$. When the deoxycholate concentration was $0.06 \%$ (corresponding to LPS $1375 \mu \mathrm{g} . / \mathrm{ml}$.) no inactivation of the o-I phage was observed. After dilution of deoxycholate to less than $0.03 \%$ the phage inactivating ability was restored. - - LPS of strain R 60 where the deoxycholate was removed by dialysis; $\mathrm{PhI} 50=\mathrm{I}_{10} \mu \mathrm{g}$. LPS $/ \mathrm{ml}$.; $\triangle-\triangle$, LPS of strain $\mathrm{R} 60$ after further treatment by phenol + water extraction, PhI $50=17 \mu \mathrm{g}$. LPS ml. 
Treatment of lipopolysaccharide from strain $\mathrm{R} 60$ with sodium deoxycholate $(S D C)$

Lyophilized LPS from strain $\mathrm{R} 60$ was dissolved in 0.1 M-tris-buffer (pH 8.0) and SDC added to a final concentration of $0.5 \%(\mathrm{w} / \mathrm{v})$. After addition of SDC the opalescence of the LPS suspension disappeared almost completely. The PhI 50 of the LPS from strain $\mathrm{R} 60$ preparation was $0.5 \mu \mathrm{g} . / \mathrm{ml}$. Addition of SDC resulted in a dramatic decrease in the O-I phage inactivating ability to a $\mathrm{PhI} 50$ value corresponding to $275^{\circ}$ $\mu \mathrm{g}$. LPS $/ \mathrm{ml}$. (Fig. 2). When the concentration of SDC was diluted with $\mathrm{M} 9$ medium to less than $0.03 \%$ the receptor activity of the LPS was restored. No decrease in the infectivity of the O-I phage was observed in control experiments with $0.5 \%(\mathrm{w} / \mathrm{v})$ SDC, nor did this concentration interfere with the adsorption of the phage to sensitive bacteria.

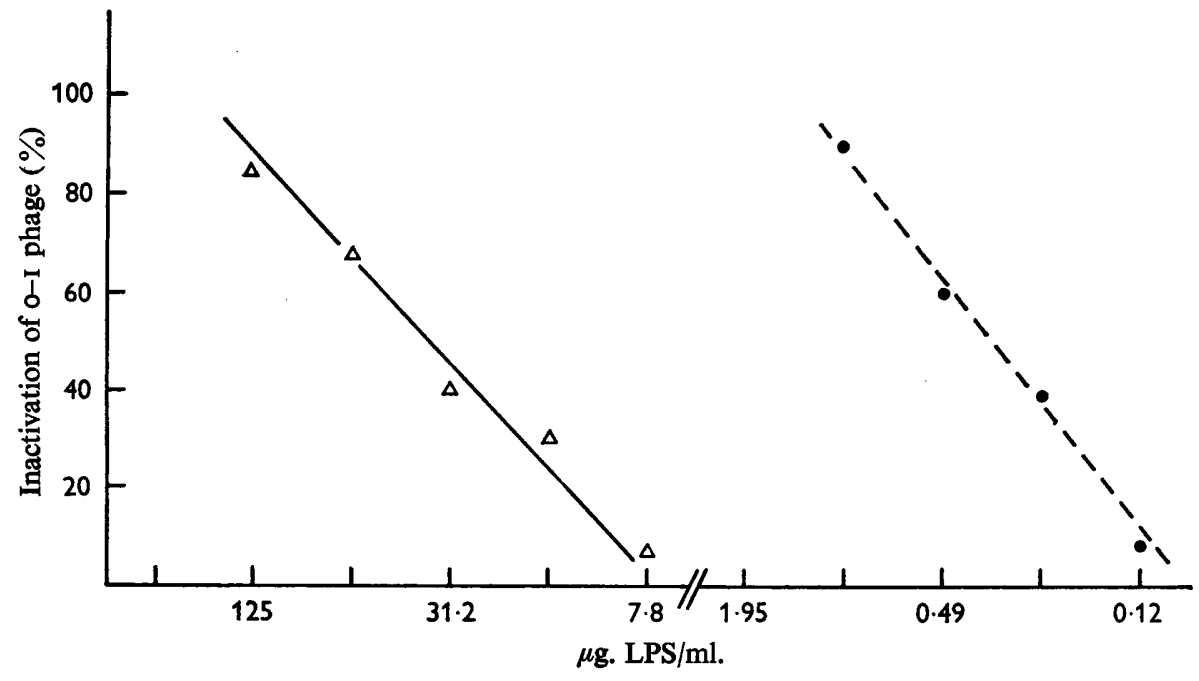

Fig. 3. Effect of ultrasonic treatment of lipopolysaccharide from Salmonella minnesota strain R60. The O-I phage inactivating capacity of the LPS is expressed as PhI 50. LPS of strain $\mathrm{R} 60$ before ultrasonic treatment; PhI $50=0.35 \mu \mathrm{g}$. LPS $/ \mathrm{ml}$.; $\triangle-\triangle$, LPS of strain R 60 after $5 \mathrm{~min}$. ultrasonic treatment, $\mathrm{PhI} 50=35 \mu \mathrm{g}$. LPS $/ \mathrm{ml}$.

The deoxycholate was removed by dialysis against $0 \cdot I$ M-tris buffer and against the defined medium $\mathbf{M} 9$. The dialysis against medium $M 9$ restored the optimal conditions for O-I phage adsorption. The inactivating capacity of the LPS suspension increased after dialysis to a $\mathrm{PhI} 50$ corresponding to I Io $\mu \mathrm{g}$. LPS $/ \mathrm{ml}$. After treatment of the dialysed LPS suspension with phenol, the inactivating ability was further increased to a $\mathrm{PhI} 50$ value corresponding to $17 \mu \mathrm{g}$. $\mathrm{LPS} / \mathrm{ml}$.

The processes were directly observed by electron microscopy. Intact LPS of R60 appeared as long filaments with a uniform width (P1. I, fig. 3). When this LPS of R60 was treated with $0.5 \%$ SDC the filaments dissociated into elements which could not be seen with the electron microscope, i.e. the deoxycholate which had dried on the grid covered them. However, when the deoxycholate was removed by dialysis the elements re-associated into units which could be observed as a population of short rods, spherical and irregular particles (P1. 2, fig. 5). The size varied from 100 to $400 \AA \AA$.

The dissociated $\mathrm{R} 60$ lipopolysaccharide was further aggregated when the suspension 
was treated by phenol + water extraction. Plate 2, fig. 6 shows a representative field; some filaments are more than $1000 \AA$ long and there are rods from 300 to $500 \AA$ long. The width of the filaments varied from 60 to $100 \AA$. There were also many spherical particles measuring around $250 \AA$ in diameter. The smallest observed units of lipopolysaccharide $\mathrm{R} 60$ which adsorbed phages measured from 200 to $300 \AA$.

\section{Ultrasonic treatment of lipopolysaccharide of strain $R 60$}

Ultrasonic treatment of LPS of strain R60 decreased its O-I phage inactivating capacity to about I \% of that of the original preparation (Fig. 3). The $\mathrm{PhI} 50$ value increased from $0.4 \mu \mathrm{g}$. LPS $/ \mathrm{ml}$. to $35 \mu \mathrm{g}$. LPS $/ \mathrm{ml}$.

Electron micrographs of preparations before and after ultrasonic treatment showed great variations. The filaments had disintegrated into rods and spherical particles. Plate 2, fig. 7 is an electron micrograph showing a representative field with some rods from 600 to $900 \AA$ long. The majority of particles were rods from I50 to $240 \AA$ long and from 60 to $80 \AA$ wide. Spherical particles of diameter about $100 \AA$ could be seen.

\section{DISCUSSION}

Investigations carried out in many laboratories (Beckmann et al. I964; Nikaido et al. 1964 Osborn et al. 1964; Lüderitz et al. 1965) led to the hypothesis first proposed by Davies (1960), Kauffmann et al. (1960) and Kauffmann et al. (1961) that the $O$ antigen in Salmonella contains a central core of lipopolysaccharide common to all the salmonellas examined so far. Antigenic determinants attached to this core give the different Salmonella species their serological specificity. The o-r phage, which adsorbs to both $\mathbf{S}$ forms and to a certain class of $\mathrm{R}$-mutants, probably attaches to a cell wall structure which is common in Salmonella. As shown here in the inactivation experiments and the electron micrographs the isolated lipopolysaccharide from Salmonella minnesota strain $\mathrm{R} 60$ acts as a receptor structure for the $0-\mathrm{I}$ phage.

The non-reducing $N$-acetyl-D-glucosamine unit which probably terminates the polysaccharide core in Salmonella minnesota $\mathrm{R} 60$ may determine the specificity of the O-I phage receptor. The only difference between $S$. minnesota $\mathrm{R} 60$ and strain R 345 so far detected is that R345 lacks the glucosamine unit in the polysaccharide (Lüderitz et al. I965). As suggested by the inactivation experiments and seen with the electron microscope the lipopolysaccharide of strain R345 does not cause contraction of the tail sheath of the O-I phage. The terminal $N$-acetyl-D-glucosamine unit may in fact mediate the adsorption of the O-I phage to the lipopolysaccharide. Taylor (I966) found that the adsorption of Vi-phage II to the Vi-polysaccharide of $S$. typhi was followed by an enzymic de-acetylation of the polysaccharide. The enzyme, situated on the tip of the Vi-phage tail, split $O$-acetyl as well as $N$-acetyl groups by hydrolysis.

Ribi et al. (1966) have found that sodium deoxycholate can dissociate lipopolysaccharide endotoxins from Gram-negative bacteria into subunits with molecular weights of about 20,000 , with a subsequent loss of ability to produce fever in rabbits. The biological activity reappeared when the deoxycholate was removed. Their findings suggested another way of testing how the integrity of the lipopolysaccharide structure of Salmonella minnesota $\mathrm{R} 60$ is related to O-I phage receptor activity. By treatment of the receptor structure with deoxycholate the phage inactivating capacity decreased to less than $0.1 \%$ of that of the original lipopolysaccharide suspension (Fig. 2). The 
failure of the subunits to adsorb the o-I phage can be explained in at least two different ways: (i) the adsorption of the phage to the subunits is blocked by the presence of deoxycholate; (ii) the subunits are too small to contain a single complete site of attachment to the phage. When the concentration of deoxycholate was diluted to less than $0.03 \%$ the phage inactivating capacity was restored. This concentration may be too low either to block adsorption of phage or to keep the subunits dissociated. When the deoxycholate was removed by dialysis the subunits recombined to form complete receptor structures. The phage inactivating capacity could be further increased by phenol treatment. The experiments suggest that the inactivation of phages can be used as a simple test of the biological activity of a lipopolysaccharide along with other methods, e.g. toxicity and fever response in rabbits.

The smallest units which were found to cause ejection of the o-I phage nucleic acid and contraction of its tail sheath measured from 200 to $300 \AA$ of length. Ribi et al. (I966) have found particles of the same size to have molecular weights ranging from 500,000 to $1,000,000$. As a comparison, the soluble lipopolysaccharide receptor structure for coliphage $\mathrm{T}_{4}$ in Shigella sonnei varied from 50 to $100 \AA$ in size (Jesaitis \& Goebel, 1953). The Escherichia coli B receptor structure of phage T 5 , which contained a core of lipopolysaccharide covered with lipoprotein, has a spherical shape around $315 \AA$ (Weidel \& Kellenberger, I955).

Ultrasonic treatment caused a decrease in the o-I inactivating capacity of Salmonella minnesota $\mathrm{R} 60$ lipopolysaccharide. The observed gross morphological changes of the lipopolysaccharide of strain R60 after ultrasonic treatment might explain the difference in $0-I$ phage inactivating capacity of the two suspensions. Whereas untreated lipopolysaccharide offered a receptor structure for the phage, ultrasonic treatment disintegrated the lipopolysaccharide into smaller units with no inactivating capacity. The residual inactivating capacity after disintegration might be explained by the presence of the remaining rods still retaining intact receptor sites.

Investigations on the 0-I phage receptor have been made by the author on some of the Salmonella typhimurium mutant strains used by Subbaiah \& Stocker (I964). Isolated lipopolysaccharides from strains containing the terminal acetyl-glucosamine unit inactivated the o-I phage, whereas lipopolysaccharides from strains lacking the amino sugar did not. Thus, strains containing the central core in $S$. minnesota and $S$. typhimurium offer a receptor for the o-I phage provided that the terminal acetylglucosamine unit is present. If the central core in Salmonella represents a receptor for the o-I phage, the chemical configuration of the lipopolysaccharides of most enterobacteria must differ from that of Salmonella. Alternatively the cell wall of Enterobacteriaceae may contain the receptor which may be blocked by other surface components. Experiments are in progress to investigate the o-I phage inactivating capacity of isolated lipopolysaccharides from other Salmonella and enterobacteria strains.

This investigation was supported by a grant from Swedish Medical Research Council Project no. B 67 40X-786-02. The author thanks Miss Mary Anderzon for skilful technical assistance and $\mathrm{Mr}$ U. Schönning for handling the electron microscope. 


\section{REFERENCES}

ADAMs, M. H. (1959). Bacteriophages. New York: Interscience Publishers, Inc.

BeckmanN, I., Subbaiah, T. V. \& Stocker, B. A. D. (1964). Rough mutants of Salmonella typhimurium. 2. Serological and chemical investigations. Nature, Lond. 201, 1299.

Beumer, J. \& DiRkX, J. (1960). Isolement de substances réceptrices des bactériophages chez les Shigellae. Annls Inst. Pasteur, Paris 98, 910.

BRENNER, S. \& HoRNe, R. W. (1959). A negative staining method for high resolution electron microscopy of viruses. Biochim. biophys. Acta 34, 103.

BuRnet, F. M. (1934). The phage-inactivating agent of bacterial extracts. J. Path. Bact. 38, 285.

Cherry, W. B., Davis, B. R., Edwards, P. R. \& Hogan, R. B. (I954). A simple procedure for the identification of the genus Salmonella by means of a specific bacteriophage. J. Lab. clin. Med. 44, 5 I.

Davies, D. A. L. (1960). Polysaccharides of Gram-negative bacteria. Adv. Carbohyd. Chem. 15, 271.

Feldx, A. \& Callow, B. R. (1943). Typing of paratyphoid B bacilli by means of Vi bacteriophage. Br. med. J. 2, 127.

Hotchin, J. E., Dawson, I. M. \& Elford, W. J. (I952). The use of empty bacterial membranes in the study of the adsorption of Staphylococcus $\mathrm{K}$ phage upon its host. Br. J. exp. Path. 33, I77.

JeSAITIS, M. A. \& Goebel, W. F. (1953). Mechanism of phage action. Nature, Lond. 172, 622.

KallingS, L. O. (1967). Sensitivity of various salmonella strains to Felix o-I phage. Acta path. microbiol. scand. (in the Press).

Kallings, L. O. \& Lindberg, A. A. (1967). Resistance to Felix o-I phage in Salmonella bacteria. Acta path. microbiol. scand. (in the Press).

Kauffmann, F., Lüderitz, O., Stierlin, H. \& WestPhal, O. (1960). Zur Immunchemie der OAntigene von Enterobacteriaceae. I. Analyse der Zuckerbausteine von Salmonella O-Antigenen. Zentbl. Bakt. ParasitKde. Abt. I. Orig. I78, 442.

KauffManN, F., KRÜGeR, L., LÜDERTTZ, O. \& WeSTPhal, O. (I96I). Zur Immunchemie der OAntigene von Enterobacteriaceae. VI. Vergleich der Zuckerbausteine von Polysacchariden aus Salmonella-S-und R-Formen. Zentbl. Bakt. ParasitKde, Abt. I, Orig. r82, 57.

LeVIne, P. \& Frisch, A. W. (1933a). Specific inhibition of bacteriophage by bacterial extracts. Proc. Soc. exp. Biol. Med. 30, 993.

LeVINe, P. \& FrisCH, A. W. (1933b). Further observations on specific inhibition of bacteriophage action. Proc. Soc. exp. Biol. Med. 3r, 46.

LEVINE, P. \& Frisch, A. W. (1934). On specific inhibition of bacteriophage action by bacterial extracts. J. exp. Med. 59, 2 I3.

Lüderitz, O., Risse, H. J., Schulte-Holthausen, H., Strominger, J. L., Sutherland, I. W. \& WESTPHAL, O. (1965). Biochemical studies of the smooth-rough mutation in Salmonella minnesota. J. Bact. 89, 343.

Nikamo, H., Nikaido, K., Subbaiah, T. V. \& Stocker, B. A. D. (1964). Rough mutants of Salmonella typhi-murium. 3. Enzymatic synthesis of nucleotide sugar compounds. Nature, Lond. 2or, I301.

Oroszlan, S. I. \& Mora, P. T. (1963). Dissociation and reconstitution of an endotoxin. Biochem. biophys. Res. Commun. 12, 345.

Osborn, M. J., Rosen, S. M., Rothfield, L., Zeleznick, L. D. \& HoRecker, B. L. (1964), Lipopolysaccharide of the Gram-negative cell wall. Science, N.Y. 145, 783 .

Ribi, E., Anacker, R. L., Brown, R., Haskins, W. T., Malmgren, B., Milner, K. C. \& Rudbach, J. A. (I966). Reaction of endotoxin and surfactants. I. Physical and biological properties of endotoxin treated with sodium deoxycholate. J. Bact. 92 , 1493.

SEIDEL, G. (1956). Úber dieSpezifität des O-Phagentestes für die Salmonella-Diagnostik. 2. Colloquium über Fragen der Lysotypie, p. 69. Zentrallaboratorium für Lysotypie, Bezirks-Hygiene-Institut Wernigerode (Harz).

Subbaiah, T. V. \& Stocker, B. A. D. (1964). Rough mutants of Salmonella typhi-murium. I. Genetics Nature, Lond. 201, 1298.

TAYLOR, K. (I966). Physical and chemical changes of Vi-polysaccharide due to Vi-phage II action. Acta biochim. pol. 13, 97 . 
Journal of General Microbiology, Vol. 48, No. 2

Plate 1
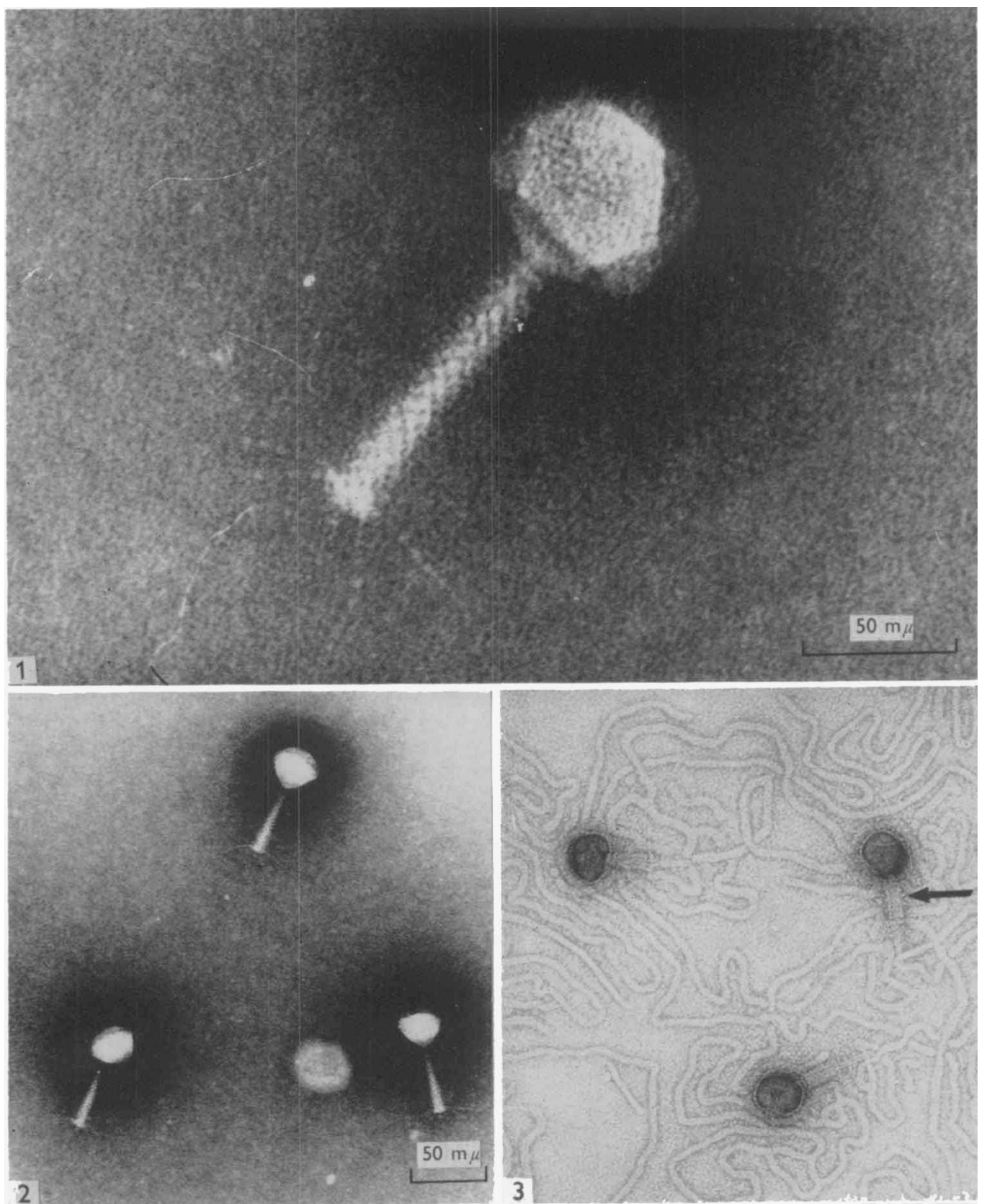

A. A. LINDBERG

(Facing p. 232) 

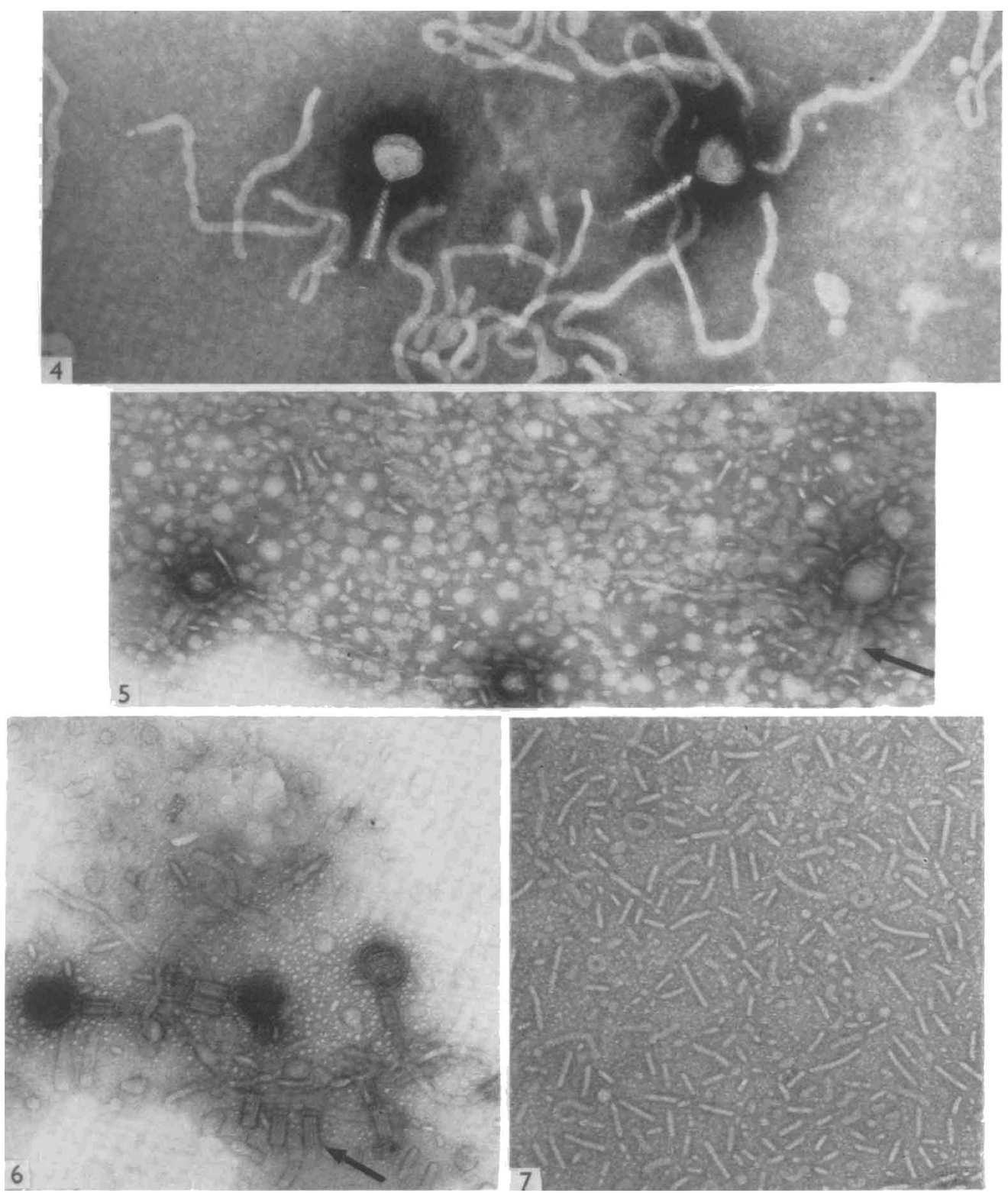

A. A. LINDBERG 
Thal, E. \& Kallings, L. O. (1955). Zur Bestimmung des Genus Salmonella mit Hilfe eines Bakteriophagen. Nord. VetMed. 7, I063.

WeIDEL, W. (I95I). Über die Zellmembran von Escherichia coli B. I. Präparierung der Membranen gegenüber den Bakteriophagen der T-Serie. $Z$. Naturf, 6b, 251 .

WeIDEL, W. \& Kellenberger, E. (1955). The E. coli B receptor for the phage T 5. II. Electron microscopic studies. Biochim. biophys. Acta I7, I.

WestPhal, O., Lüderitz, O. \& Bister, F. (1952). Über die Extraktion von Bakterien mit Phenol Wasser. Z. Naturf. $7 b$, $\mathbf{1 4 8}$.

\section{EXPLANATION OF PLATES}

The magnification in figs. $5-10$ is $\times 100,000$ and in fig. $4 \times 400,000$. The $0-1$ phage and the lipopolysaccharide were negatively stained with sodium tungstic silicate (STS).

Figs. I, 2. Felix o-I phage.

\section{Plate I}

Fig. 3. Lipopolysaccharide isolated from Salmonella minnesota strain $\mathrm{R} 60$ with adsorbed 0-I phage particles. The tail sheaths (indicated by an arrow) are contracted.

\section{Plate 2}

Fig. 4. Lipopolysaccharide isolated from Salmonella minnesota strain R 345 and o-I phage. No phage adsorbed on to the lipopolysaccharide.

Fig. 5. Lipopolysaccharide of strain R60 after treatment with sodium deoxycholate and subsequent dialysis. Two of the 0-1 particles are seen with contracted tail sheaths, one has an uncontracted tail sheath (indicated by an arrow).

Fig. 6. The sodium deoxycholate treated lipopolysaccharide of strain $\mathbf{R} 60$ after dialysis and phenol+ water extraction. The o-I particles are adsorbed on to the LPS. Some detached contracted tail sheaths (indicated by an arrow) are also seen.

Fig. 7. Lipopolysaccharide from Salmonella minnesota strain R 60 after $5 \mathrm{~min}$. ultrasonic treatment. 